\title{
Maintained therapeutic effect of revefenacin over 52 weeks in moderate to very severe Chronic Obstructive Pulmonary Disease (COPD)
}

\author{
James F. Donohue ${ }^{1}$, Edward Kerwin², Sanjay Sethi ${ }^{3}$, Brett Haumann ${ }^{4}$, Srikanth Pendyala ${ }^{4}$, Lorna Dean ${ }^{4}$, \\ Chris N. Barnes ${ }^{4}$, Edmund J. Moran ${ }^{4}$ and Glenn Crater ${ }^{4^{*}}$ (D)
}

\begin{abstract}
Background: Revefenacin is a long-acting muscarinic antagonist that was recently approved for the nebulized treatment of chronic obstructive pulmonary disease (COPD). Although shorter duration studies have documented the efficacy of revefenacin in COPD, longer-term efficacy has not been described. In a recent 52-week safety trial, revefenacin was well tolerated and had a favorable benefit-risk profile. Here we report exploratory efficacy and health outcomes in patients receiving revefenacin $175 \mu \mathrm{g}$ or $88 \mu \mathrm{g}$ daily during the 52-week trial.
\end{abstract}

Methods: In this randomized, parallel-group, 52-week trial (NCT02518139), 1055 participants with moderate to very severe COPD received revefenacin $175 \mu \mathrm{g}$ or $88 \mu \mathrm{g}$ in a double-blind manner, or open-label active control tiotropium.

Results: Over the 52-week treatment period, both doses of revefenacin, as well as tiotropium, elicited significant (all $p<0.0003$ ) improvements from baseline in trough forced expiratory volume in $1 \mathrm{~s}\left(\mathrm{FEV}_{1}\right)$. The trough $\mathrm{FEV}_{1}$ profile (least squares mean change from baseline) for revefenacin $175 \mu \mathrm{g}$ ranged from $52.3-124.3 \mathrm{~mL}$ and the trough $\mathrm{FEV}_{1}$ profile for tiotropium ranged from 79.7-112.8 $\mathrm{mL}$. In subgroup comparisons, the effect of revefenacin on trough $\mathrm{FEV}_{1}$ was comparable in patients taking concomitant long-acting $\beta$-agonists, with or without inhaled corticosteroids, with patients who were not taking these medications. There were statistically significant $(p<0.05)$ improvements in all measured health status outcomes (evaluated using St. George's Respiratory Questionnaire, COPD Assessment Test, Clinical COPD Questionnaire and Baseline and Transition Dyspnea Index) from 3 months onward, in all treatment arms.

Conclusions: Significant sustained improvements from baseline in trough $\mathrm{FEV}_{1}$ and respiratory health outcomes were demonstrated for $175-\mu \mathrm{g}$ revefenacin over 52 weeks, further supporting its use as a once-daily bronchodilator for the nebulized treatment of patients with COPD.

Trial registration: NCT02518139; Registered 5 August 2015.

\section{Background}

Treatment with bronchodilators is central to the management of chronic obstructive pulmonary disease (COPD). Treatment guidelines produced by the Global Initiative for Chronic Obstructive Lung Disease (GOLD) recommend inhalation therapy with long-acting muscarinic antagonist (LAMA) or long-acting $\beta$-agonist

\footnotetext{
* Correspondence: gcrater@theravance.com

${ }^{4}$ Theravance Biopharma US, Inc., 901 Gateway Boulevard, South San Francisco, CA 94080, USA

Full list of author information is available at the end of the article
}

(LABA) bronchodilators as first-line therapy to address COPD symptoms and prevent exacerbations [1]. The use of an inhaled corticosteroid (ICS) in combination with LABA or LABA/LAMA therapy is recommended for patients experiencing exacerbations despite the use of bronchodilator therapy [1].

Until recently, LAMAs were not available in a nebulized form. The LAMA glycopyrrolate bromide was recently approved (2017) for twice-daily nebulized delivery via a custom-designed electronic vibrating mesh nebulizer (eFlow ${ }^{\otimes}$; Lonhala ${ }^{\circ}$ Magnair ${ }^{\circ}$, Sunovion; Marlborough, MA, 
USA) [2]. Revefenacin, a novel, lung-selective LAMA, was approved by the US Food and Drug Administration (FDA) in November 2018 at a $175 \mu \mathrm{g}$ dose, for once-daily nebulized delivery via a standard jet nebulizer for the maintenance treatment of COPD [3]. Beyond the differences in frequency and method of administration, revefenacin is a different molecular class than glycopyrrolate bromide-it is a tertiary amine, not a quaternary ammonium compound. Thus, it is a different molecular class from all the inhaled muscarinic antagonists (glycopyrrolate bromide, tiotropium bromide [tiotropium], umeclidinium bromide, aclidinium and ipratropium bromide) available to date. Revefenacin was designed to produce sustained local bronchodilation with minimal systemic drug exposure [4, 5], and as a result appears to have lower potential for systemic anti-muscarinic side effects than quaternary ammonium compounds [6].

Replicate 12-week pivotal phase 3 trials demonstrated significant bronchodilation in patients with moderate to very severe COPD taking once-daily inhaled revefenacin at doses of $175 \mu \mathrm{g}$ and $88 \mu \mathrm{g}$, with or without concomitant LABA/ICS therapy [7]. The safety and tolerability of revefenacin over 52 weeks has been presented previously [8]. Here we report the maintained therapeutic effect of revefenacin and improvement in health outcomes versus tiotropium over the course of 52 weeks in patients with moderate to very severe COPD.

\section{Methods}

\section{Study design and conduct}

This was a phase 3, randomized, partially doubleblinded, parallel-group 52-week trial (NCT02518139). The trial was conducted in accordance with the principles of the International Council on Harmonisation of Technical Requirements for Pharmaceuticals for Human Use guideline for good clinical practice [9], and the code of ethics of the World Medical Association's Declaration of Helsinki [10], and all patients provided written informed consent.

\section{Patients and treatments}

Study design, participants and treatments have been described previously [8]. Briefly, patients were required to meet the criteria for moderate-to-severe COPD, which included $<0.7$ postipratropium forced expiratory volume in $1 \mathrm{~s}\left(\mathrm{FEV}_{1}\right) /$ forced vital capacity ratio and $<80 \%$ postipratropium $\mathrm{FEV}_{1}$ of predicted normal but at least $700 \mathrm{~mL}$ [11]. Patients were excluded if they had significant respiratory disease other than COPD, elevated cardiovascular risk (e.g., myocardial infarction or unstable angina within the previous 6 months, unstable or lifethreatening arrhythmia requiring intervention in the previous 3 months, or New York Heart Association Class IV heart failure) or exhibited a clinically significant abnormality in 12-lead electrocardiogram at screening, or uncontrolled hypertension, hypercholesterolemia, or type 2 diabetes. In addition, patients were ineligible for participation if they had been hospitalized for COPD or pneumonia within 8 weeks of screening or had used systemic corticosteroids or antibiotics within 6 weeks of screening. Patients were equally randomized to receive revefenacin $175 \mu \mathrm{g}$ or $88 \mu \mathrm{g}$, or tiotropium $18 \mu \mathrm{g}$, for 52 weeks. Revefenacin dose was assigned in a double-blind manner, and the drug was administered using a standard jet nebulizer (PARI LC ${ }^{\circ}$ Sprint; Midlothian, VA, USA). Tiotropium was administered open label using the HandiHaler ${ }^{\circ}$ device (Spiriva ${ }^{\circ}$ HandiHaler; Boehringer Ingleheim, Ridgefield, CT, USA). Stratified randomization was used to randomize patients according to their reversibility status to ipratropium and use of concomitant LABA or LABA/ ICS treatment at screening.

\section{Assessments and endpoints}

The primary endpoint results (safety and tolerability of revefenacin as a treatment for COPD over 52 weeks) were previously reported [8]. Here we report exploratory efficacy and health outcomes endpoints and use of rescue medication, all of which were evaluated as change from baseline (and not as between-treatment comparison). These exploratory endpoints included the change in trough $\mathrm{FEV}_{1}$, changes in health outcomes using general and COPD-specific respiratory symptom rating instruments (St. George's Respiratory Questionnaire [SGRQ], COPD Assessment Test [CAT], Clinical COPD Questionnaire [CCQ], EXAcerbation of Chronic Pulmonary Disease Tool Patient Related Outcome [EXACT-PRO], Baseline and Transition Dyspnea Index [BDI/TDI]), and concomitant use of rescue medications, all over 12 months.

Change from baseline in $\mathrm{FEV}_{1}$ was measured prior to drug administration at 1, 3, 6, 9 and 12 months (Days 29, 92, 183, 274 and 365). Patient-reported outcomes (SGRQ, CAT, CCQ, BDI/TDI) were assessed in the clinic on Days 1, 92, 183, 274 and 365; EXACT-PRO [12], a patientreported outcome electronic diary designed to count and characterize symptom-defined exacerbations was used by patients each night. Treatment satisfaction was measured using a non-validated treatment satisfaction questionnaire at screening and on Day 365.

The minimal clinically important difference (MCID) for each assessed outcome was used to determine response to treatment (responders). For SGRQ, a reduction in mean baseline score of 4 points is considered clinically relevant. Although there is no generally accepted MCID for the CAT, a change of 2 points appears to be clinically relevant and correlates well with the MCID of other validated health status measures. For CCQ, the validated MCID is 0.4, and for TDI the 
benchmark is a difference between groups in total score of $\geq 1$ point. For this study, patients who met or exceeded the MCID on each measure were considered responders.

Patients documented whether or not they used the albuterol metered dose inhaler as rescue medication over each 24-h period in a study diary. In addition, the number of puffs from the inhaler was recorded by study site personnel at each clinic visit. Rescue albuterol use (number of puffs per day) was averaged over the 12-month treatment period and reported for Months 1, 3, 6, 9 and 12. Data for analysis were drawn from inhaler counter totals recorded in the electronic case report form and not the self-reported data, as inhaler counters were considered to be more reliable.

\section{Statistical analyses}

The exploratory analyses were performed using the intent-to-treat (ITT) population, defined as all randomized patients who received at least one dose of study drug and had at least one postbaseline $\mathrm{FEV}_{1}$ measurement.

Trough $\mathrm{FEV}_{1}$ was defined as the mean of the - 45- and -15-min pre-dose spirometry assessments and evaluated using a repeated measures mixed-effect model (RMMM) model. Treatment group, smoking status, ipratropium reversibility status, concomitant LABA/ICS use at baseline, sex and age at baseline ( $\leq 65$ years or $>65$ years) were fixed effects. A covariate for baseline $\mathrm{FEV}_{1}$ was included. A time effect and its interaction with treatment and baseline $\mathrm{FEV}_{1}$, as well as a random effect for subject nested within site/center was included in the model. Within-subject correlation was modelled using an unstructured covariance. Pre-specified subgroup analyses were performed for the change from baseline in trough $\mathrm{FEV}_{1}$ among patients who used a LABA-containing product or ICS, were $\geq 65$ years old and were current smokers.

SGRQ, CAT and BDI/TDI were summarized as continuous measures using absolute values and change from baseline at each visit, and as a proportion using a responder definition. The CCQ data were summarized as continuous measures using absolute values and change from baseline at each visit.

Treatment satisfaction was summarized using descriptive statistics. The number of puffs of rescue medication and number of rescue medication-free days were analyzed using a RMMM model with the same independent variables as those described for $\mathrm{FEV}_{1}$.

The primary endpoint of this study was to assess long term safety and tolerability of revefancin, and therefore was not designed or powered to show differences between treatments.

\section{Results}

\section{Patients}

Of the 1060 patients randomized to treatment, 1055 received at least one dose of study drug. The ITT analysis set comprised 1020 patients (revefenacin $175 \mu \mathrm{g}, n=319$; revefenacin $88 \mu \mathrm{g}, n=350$; tiotropium, $n=351$ ). Patient demographics and baseline characteristics in the ITT population were similar between treatment groups (Table 1).

Over the year-long study, there were more withdrawals from the revefenacin treatment arms (39-43\%) than from the tiotropium arm (26\%), which led to wider confidence intervals (CIs) and more variable data at the 9and 12-month time points for all treatment arms (Table 2). A higher percentage of subjects in the revefenacin groups discontinued study drug in the first 3 months $(60 / 335$ [17.9\%] and 50/368 [13.6\%] in the revefenacin $175 \mu \mathrm{g}$ and $88 \mu \mathrm{g}$ groups, respectively) compared with the tiotropium group (25/357, [7.0\%]). There were 2-3 times more withdrawals from the revefenacin arms in the "withdrawal by subject" category compared with the tiotropium arm (Table 2). A review of those subjects reported as discontinuing the treatment period for the reason "withdrawal by subject" indicated that patients did not appear to drop out of the revefenacin arms of the study due to lack of efficacy. A post hoc analysis of withdrawal by $\mathrm{FEV}_{1}$ response showed, that patients in the revefenacin $175 \mu \mathrm{g}$ group had greater $\mathrm{FEV}_{1}$ improvements from baseline versus the tiotropium group at various time points (Additional file 1: Table S1).

The percentage of subjects who discontinued treatment due to adverse events (AEs) was similar in both revefenacin groups $(12-13 \%)$ and lower in the tiotropium group (9\%). However, with respect to the most commonly reported AEs, a similar percentage of subjects across groups $(<2.5 \%)$ discontinued study drug due to COPD exacerbation, whereas more subjects in the revefenacin groups $(1.8 \%$ and $2.5 \%$ in the $175 \mu \mathrm{g}$ and $88 \mu \mathrm{g}$ groups, respectively) discontinued due to dyspnea compared with the tiotropium group (0.6\%).

\section{Efficacy}

Over the 52-week treatment period, both doses of revefenacin, as well as tiotropium, elicited statistically significant (all $p<0.0003$ ) improvements from baseline in trough $\mathrm{FEV}_{1}$ (Table 3, Fig. 1a). The trough $\mathrm{FEV}_{1}$ profile for revefenacin $175 \mu \mathrm{g}$ (range, $52.3-124.3 \mathrm{~mL}$ ) was similar to that of tiotropium (range, 79.7-112.8 mL) up to Month 9, but diverged after that, in part due to differences in subject discontinuation in the final 3 months of the trial (Table 4).

In subgroup comparisons, the effects on trough $\mathrm{FEV}_{1}$ among patients who were using a LABA ranged from $51.8-102.9 \mathrm{~mL}$ with revefenacin $175 \mu \mathrm{g}$, and $64.7-102.5$ $\mathrm{mL}$ with tiotropium (Fig. 1b). All subgroups responded similarly overall in the three treatment arms (Fig. 2).

\section{Health outcomes assessments}

There was a statistically significant $(p<0.05)$ improvement in SGRQ, CAT and CCQ at all time points 
Table 1 Baseline patient demographics and clinical characteristics (ITT population)

\begin{tabular}{|c|c|c|c|}
\hline Characteristic & Revefenacin $88 \mu \mathrm{g}(n=350)$ & Revefenacin $175 \mu \mathrm{g}(n=319)$ & Tiotropium $18 \mu \mathrm{g}(n=351)$ \\
\hline Age, $y$, mean (SD) & $64.2(9.37)$ & $64.5(8.61)$ & $64.9(8.91)$ \\
\hline Sex, male, $n(\%)$ & $197(56.3)$ & $188(58.9)$ & $211(60.1)$ \\
\hline Race, white, $n(\%)$ & $324(92.6)$ & $294(92.2)$ & $326(92.9)$ \\
\hline $\mathrm{BMI}, \mathrm{kg} / \mathrm{m}^{2}$, mean (SD) & $28.9(6.6)$ & $29.0(6.6)$ & $28.8(6.3)$ \\
\hline Current smoker, $n(\%)$ & $163(46.6)$ & $140(43.9)$ & $164(46.7)$ \\
\hline \multicolumn{4}{|l|}{ Concurrent COPD medication use, $n(\%)$} \\
\hline ICS & $191(54.6)$ & $165(51.7)$ & $187(53.3)$ \\
\hline$\angle A B A$ or ICS/LABA & $175(50.0)$ & $158(49.5)$ & $177(50.4)$ \\
\hline ICS/LABA & $170(48.6)$ & $146(45.8)$ & $172(49.0)$ \\
\hline COPD duration, $y$, mean (SD) & $9.3(6.98)$ & $8.7(5.92)$ & $9.5(6.84)$ \\
\hline \multicolumn{4}{|l|}{2011 GOLD a category, n (\%) } \\
\hline A & $31(8.9)$ & $20(6.3)$ & $23(6.6)$ \\
\hline B & $184(52.6)$ & $165(51.7)$ & $183(52.1)$ \\
\hline C & $7(2.0)$ & $7(2.2)$ & $5(1.4)$ \\
\hline $\mathrm{D}$ & $128(36.6)$ & $123(38.6)$ & $136(38.7)$ \\
\hline Unknown & 0 & $4(1.3)$ & $4(1.1)$ \\
\hline \multicolumn{4}{|l|}{2011 GOLD a airflow limitation category, n (\%) } \\
\hline 2 & $222(61.0)$ & $201(60.0)$ & $210(59.0)$ \\
\hline 3 & $122(33.5)$ & $109(32.5)$ & $124(34.8)$ \\
\hline 4 & $20(5.5)$ & $25(7.5)$ & $22(6.2)$ \\
\hline Postipratropium percent predicted $\mathrm{FEV}_{1}, \%$, mean (SD) & $54.29(14.1)$ & $53.75(14.8)$ & $53.15(14.2)$ \\
\hline Postipratropium FEV 1 to FVC ratio, mean (SD) & $0.54(0.10)$ & $0.53(0.10)$ & $0.53(0.10)$ \\
\hline Baseline $\mathrm{FEV}_{1}, \mathrm{~L}$, mean (SD) & $1.34(0.5)$ & $1.34(0.5)$ & $1.32(0.5)$ \\
\hline Proportion of patients with baseline mMRC $\geq 2, n(\%)$ & $181(51.7)$ & $170(53.3)$ & $180(51.3)$ \\
\hline Proportion of patients with baseline CAT $\geq 10, n(\%)$ & $312(89.1)$ & $288(90.3)$ & $319(90.9)$ \\
\hline \multicolumn{4}{|l|}{ Number of COPD exacerbations in prior year, $n(\%)$} \\
\hline 0 & $264(75.4)$ & $242(75.9)$ & $271(77.2)$ \\
\hline 1 & $59(16.9)$ & $50(15.7)$ & $52(14.8)$ \\
\hline$\geq 2$ & $27(7.7)$ & $27(8.5)$ & $28(8.0)$ \\
\hline
\end{tabular}

2011 GOLD criteria. (Global Initiative for Obstructive Lung Disease. Global strategy for the diagnosis, management and prevention of chronic obstructive pulmonary disease. 2011. http://goldcopd.com)

$B M I$ body mass index, CAT COPD assessment test, COPD chronic obstructive pulmonary disease, $F E V_{1}$ forced expiratory volume in $1 \mathrm{~s}$, FVC forced vital capacity, GOLD Global Initiative for Chronic Obstructive Lung Disease, ICS inhaled corticosteroids, ITT intent-to-treat, LABA long-acting beta agonist, $m M R C$ modified Medical Research Council, SD standard deviation

assessed from 3 months for all three treatment arms (Fig. 3). Analysis of MCID response based on SGRQ total score at Day 365 revealed that there was a similar percentage of responders in the tiotropium, revefenacin $175 \mu \mathrm{g}$ and revefenacin $88 \mu \mathrm{g}$ groups (53\%, $42 \%$ and $45 \%$ respectively). The percentage of CAT responders in all three treatment groups were similar (revefenacin $175 \mu \mathrm{g}$ [48\%] revefenacin $88 \mu \mathrm{g}$ group [43\%] and tiotropium group [47\%]). Changes in CAT and CCQ scores did not reach the pre-determined thresholds for clinical significance in any group at any time point.

The revefenacin $175 \mu$ g group had 153 COPD exacerbations and the rate of exacerbations (1.78; 95\% CI: 1.37 ,
2.30) during the year of treatment was based on data from the EXACT-PRO tool. The lower-dose revefenacin and tiotropium groups reported 197 and 192 exacerbations, and exacerbation rates of 2.46 (95\% CI: 1.93, 3.15) and 2.31 (95\% CI: 1.78, 2.99), respectively. Mean exacerbation severity scores were similar between treatment groups (53 to 54 on a 0 to 100 scale, in which higher scores indicate more severe disease). Data from the EXACT-PRO tool supported the study's findings based on evaluation of COPD exacerbations reported as treatment-emergent AEs [8].

Evaluation of breathlessness using the TDI total score, in which lower scores represent worsening dyspnea, 
Table 2 Patients withdrawals during the 1-year treatment period

\begin{tabular}{|c|c|c|c|c|c|c|c|}
\hline & $\mathrm{AE}, n(\%)$ & $\begin{array}{l}\text { Lost to follow-up, } \\
n(\%)\end{array}$ & $\begin{array}{l}\text { Physician } \\
\text { decision, n (\%) }\end{array}$ & $\begin{array}{l}\text { Protocol } \\
\text { deviation, } n \text { (\%) }\end{array}$ & $\begin{array}{l}\text { Withdrawal by } \\
\text { subject, } n(\%)\end{array}$ & $\begin{array}{l}\text { Other, } \\
n(\%)\end{array}$ & Total, $n(\%)$ \\
\hline Revefenacin $88 \mu \mathrm{g}$ & $(n=368)$ & & & & & & \\
\hline Days $1-30$ & $11(3.0)$ & - & $1(0.3)$ & - & $9(2.4)$ & - & $21(5.7)$ \\
\hline Days 31-92 & $11(3.0)$ & $3(0.8)$ & - & - & $15(4.1)$ & - & $29(7.9)$ \\
\hline Days 93-183 & $11(3.0)$ & $7(1.9)$ & $2(0.5)$ & $1(0.3)$ & $25(6.8)$ & $1(0.3)$ & $47(12.8)$ \\
\hline Days $184-274$ & $7(1.9)$ & $6(1.6)$ & - & $1(0.3)$ & $13(3.5)$ & $1(0.3)$ & $28(7.6)$ \\
\hline Days 275-364 & $7(1.9)$ & $5(1.4)$ & - & - & $8(2.2)$ & - & $20(5.4)$ \\
\hline Total & $47(12.8)$ & $21(5.7)$ & $3(0.8)$ & $2(0.5)$ & $70(19.0)$ & $2(0.5)$ & $145(39.4)$ \\
\hline Revefenacin $175 \mu \mathrm{g}$ & $(n=335)$ & & & & & & \\
\hline Days 1-30 & $6(1.8)$ & $1(0.3)$ & - & - & $11(3.3)$ & - & $18(5.4)$ \\
\hline Days 31-92 & $11(3.3)$ & $2(0.6)$ & - & - & $28(8.4)$ & $1(0.3)$ & $42(12.5)$ \\
\hline Days 93-183 & $11(3.3)$ & $5(1.5)$ & $2(0.6)$ & - & $24(7.2)$ & - & $42(12.5)$ \\
\hline Days $184-274$ & $6(1.8)$ & $5(1.5)$ & - & - & $10(3.0)$ & - & $21(6.3)$ \\
\hline Days 275-364 & $8(2.4)$ & $4(1.2)$ & $1(0.3)$ & - & $7(2.1)$ & $1(0.3)$ & $21(6.3)$ \\
\hline Total & $42(12.5)$ & $17(5.1)$ & $3(0.9)$ & - & $80(23.9)$ & $2(0.6)$ & $144(43.0)$ \\
\hline Tiotropium $18 \mu \mathrm{g}$ & $(n=357)$ & & & & & & \\
\hline Days 1-30 & $3(0.8)$ & - & - & - & $3(0.8)$ & - & $6(1.7)$ \\
\hline Days 31-92 & $6(1.7)$ & $2(0.6)$ & - & $1(0.3)$ & $10(2.8)$ & - & $19(5.3)$ \\
\hline Days 93-183 & $8(2.2)$ & $3(0.8)$ & - & - & $14(3.9)$ & - & $25(7.0)$ \\
\hline Days $184-274$ & $7(2.0)$ & $5(1.4)$ & - & - & $9(2.5)$ & - & $21(5.9)$ \\
\hline Days 275-364 & $9(2.5)$ & $5(1.4)$ & $1(0.3)$ & - & $7(2.0)$ & $1(0.3)$ & $23(6.4)$ \\
\hline Total & $33(9.2)$ & $15(4.2)$ & $1(0.3)$ & $1(0.3)$ & $43(12.0)$ & $1(0.3)$ & $94(26.3)$ \\
\hline
\end{tabular}

$A E$ adverse event

indicated a decrease in breathlessness in all treatment groups throughout the study. TDI scores in the revefenacin groups and tiotropium group were (LS mean TDI total score at Day 365) 0.92, 1.37 and 0.87 in the revefenacin $175 \mu \mathrm{g}$, revefenacin $88 \mu \mathrm{g}$ and tiotropium groups, respectively. The percentage of TDI responders between treatment groups at Day 365 were 85/184 patients [LS proportion 43.8\%], 110/211 patients [50.9\%] and 103/ 244 [40.3\%] in the revefenacin $175 \mu \mathrm{g}$, revefenacin $88 \mu \mathrm{g}$ and tiotropium groups, respectively.

Evaluation of rescue albuterol use showed an average of LS mean (standard error) values of $1.6(0.23), 1.9(0.2)$ and $1.3(0.21)$ puffs per day over the 12-month treatment period in the revefenacin $175 \mu \mathrm{g}$, revefenacin

Table 3 Change from baseline in trough $\mathrm{FEV}_{1}(\mathrm{~mL})$ during the 1-year treatment period

\begin{tabular}{|c|c|c|c|}
\hline Trough FEV ${ }_{1}(\mathrm{~mL})$, LS mean $(95 \% \mathrm{Cl})$ & Revefenacin $88 \mu \mathrm{g}$ & Revefenacin $175 \mu \mathrm{g}$ & Tiotropium $18 \mu \mathrm{g}$ \\
\hline Day 29 & $\begin{array}{l}83.8(60.4,107.1) \\
n=317\end{array}$ & $\begin{array}{l}124.3(99.5,149.1) \\
n=282\end{array}$ & $\begin{array}{l}112.8(89.8,135.8) \\
n=330\end{array}$ \\
\hline Day 92 & $\begin{array}{l}81.3(57.1,105.5) \\
n=287\end{array}$ & $\begin{array}{l}100.0(73.9,126.1) \\
n=243\end{array}$ & $\begin{array}{l}97.3(73.7,120.9) \\
n=307\end{array}$ \\
\hline Day 183 & $\begin{array}{l}74.2(48.6,99.8) \\
n=239\end{array}$ & $\begin{array}{l}104.4(77.1,131.7) \\
n=210\end{array}$ & $\begin{array}{l}89.0(64.9,113.2) \\
n=283\end{array}$ \\
\hline Day 274 & $\begin{array}{l}69.5(43.4,95.6) \\
n=223\end{array}$ & $\begin{array}{l}71.4(43.2,99.6) \\
n=189\end{array}$ & $\begin{array}{l}79.7(55.0,104.3) \\
n=265\end{array}$ \\
\hline Day 365 & $\begin{array}{l}48.8(22.3,75.3) \\
n=212\end{array}$ & $\begin{array}{l}52.3(23.9,80.6) \\
n=185\end{array}$ & $\begin{array}{l}91.5(66.4,116.5) \\
n=248\end{array}$ \\
\hline
\end{tabular}

Data are mean (standard deviation)

$\mathrm{Cl}$ confidence interval, $F E V_{1}$ forced expiratory volume in $1 \mathrm{~s}, L S$ least squares 

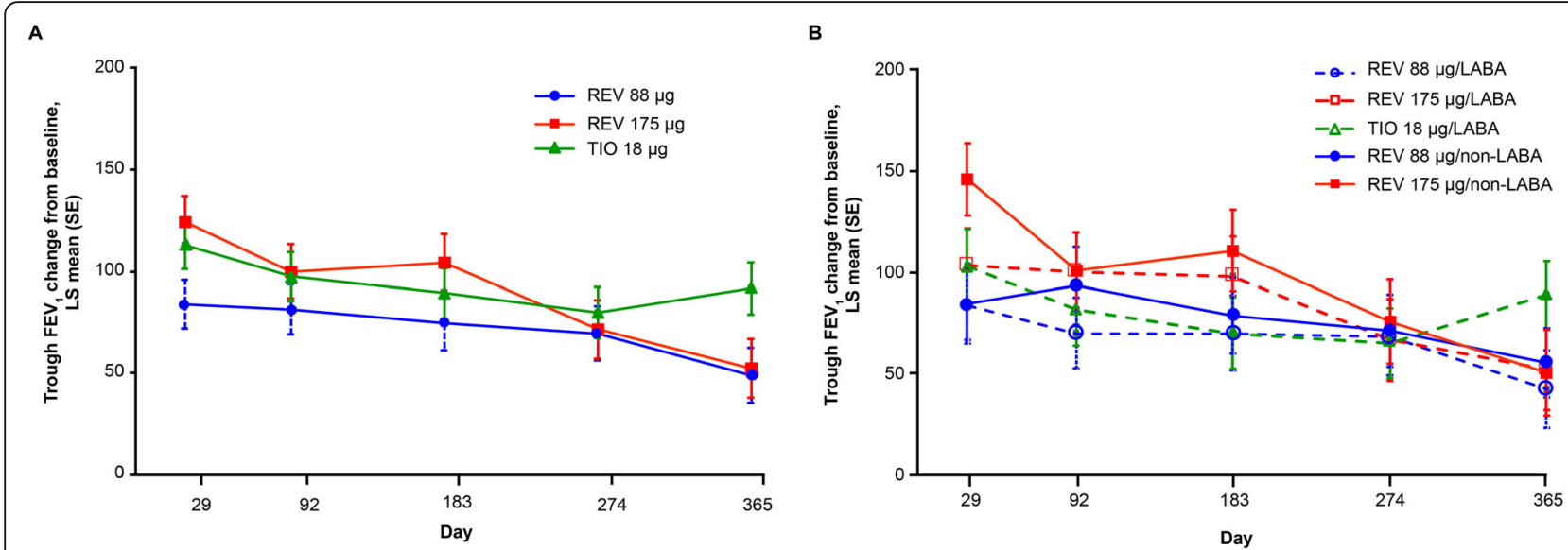

Fig. 1 Trough FEV $(\mathrm{mL})$ change from baseline during the 1-year treatment period (a) for the overall study population and (b) in subgroups of patients with or without concurrent use of LABA (LS mean change from baseline; ITT population). FEV ${ }_{1}$, forced expiratory volume in $1 \mathrm{~s}$; ITT, intent-to-treat; LABA, long-acting $\beta$-agonist; LS, least squares; REV, revefenacin; SE, standard error; TIO, tiotropium

$88 \mu \mathrm{g}$, and tiotropium groups, respectively. However, there was a consistent trend toward a decrease in puffs per day in all treatment groups throughout the study. The percentage of rescue-free days was similar across all groups (average LS mean percentage of rescue-free 24-h periods over the 12-month treatment period: 50-54\%).

Overall treatment satisfaction was similar at the beginning and end of treatment and across treatment groups at both time points measured.

\section{Discussion}

Maintained therapeutic effect during 1 year of once-daily treatment with revefenacin $175 \mu \mathrm{g}$ and $88 \mu \mathrm{g}$, and tiotropium $18 \mu \mathrm{g}$ is described. While the study was not powered to show differences between treatments, and is complicated by the bias introduced through open-label use of an active comparator, the report demonstrates statistically significant improvements in lung function measured by change from baseline in trough $\mathrm{FEV}_{1}$ for both revefenacin dose groups and tiotropium over the entire 52-week treatment period. In addition, health outcomes assessments used to measure the severity of disease-specific symptoms (SGRQ, CAT, CCQ and BDI/ TDI), and analysis of rescue medication use, demonstrated statistically significant improvements from baseline. Mean exacerbation severity scores were similar between treatment groups. The safety of revefenacin has been previously demonstrated [8].

The decline in lung function in all three treatment groups over the course of the 52-week trial reflects disease progression and is expected in any long-term efficacy analysis of COPD treatments. Interestingly, lung function in the

Table 4 Change from baseline in trough $\mathrm{FEV}_{1}(\mathrm{~mL})$, according to patient withdrawal, during the 1-year treatment period

\begin{tabular}{|c|c|c|c|}
\hline Trough FEV ${ }_{1}(\mathrm{~mL})$, LS mean (SE) & Revefenacin $88 \mu \mathrm{g}$ & Revefenacin $175 \mu \mathrm{g}$ & Tiotropium $18 \mu \mathrm{g}$ \\
\hline Day 29 and still on study at Day 92 & $\begin{array}{l}88.8(9.63) \\
n=278\end{array}$ & $\begin{array}{l}121.8(11.10) \\
n=232\end{array}$ & $\begin{array}{l}113.7(8.64) \\
n=296\end{array}$ \\
\hline Day 92 and still on study at Day 183 & $\begin{array}{l}84.5(10.74) \\
n=236\end{array}$ & $\begin{array}{l}100.8(11.78) \\
n=203\end{array}$ & $\begin{array}{l}104.7(8.88) \\
n=275\end{array}$ \\
\hline Day 183 and still on study at Day 274 & $\begin{array}{l}73.1(11.50) \\
n=216\end{array}$ & $\begin{array}{l}98.9(12.27) \\
n=182\end{array}$ & $\begin{array}{l}94.4(9.13) \\
n=259\end{array}$ \\
\hline Day 274 and still on study at Day 365 & $\begin{array}{l}68.3(11.46) \\
n=207\end{array}$ & $\begin{array}{l}65.6(11.71) \\
n=181\end{array}$ & $\begin{array}{l}86.1(9.21) \\
n=242\end{array}$ \\
\hline Day 29 and withdrew prior to Day 92 & $\begin{array}{l}73.4(19.25) \\
n=39\end{array}$ & $\begin{array}{l}130.8(15.48) \\
n=50\end{array}$ & $\begin{array}{l}130.8(21.37) \\
n=34\end{array}$ \\
\hline Day 92 and withdrew prior to Day 183 & $\begin{array}{l}93.1(19.21) \\
n=51\end{array}$ & $\begin{array}{l}97.3(26.50) \\
n=40\end{array}$ & $\begin{array}{l}42.7(25.92) \\
n=32\end{array}$ \\
\hline Day 183 and withdrew prior to Day 274 & $\begin{array}{l}99.4(33.22) \\
n=23\end{array}$ & $\begin{array}{l}137.2(34.49) \\
n=28\end{array}$ & $\begin{array}{l}143.5(32.19) \\
n=24\end{array}$ \\
\hline Day 274 and withdrew prior to Day 365 & $\begin{array}{l}83.4(55.68) \\
n=16\end{array}$ & $\begin{array}{l}60.0(106.42) \\
n=8\end{array}$ & $\begin{array}{l}57.0(36.85) \\
n=23\end{array}$ \\
\hline
\end{tabular}




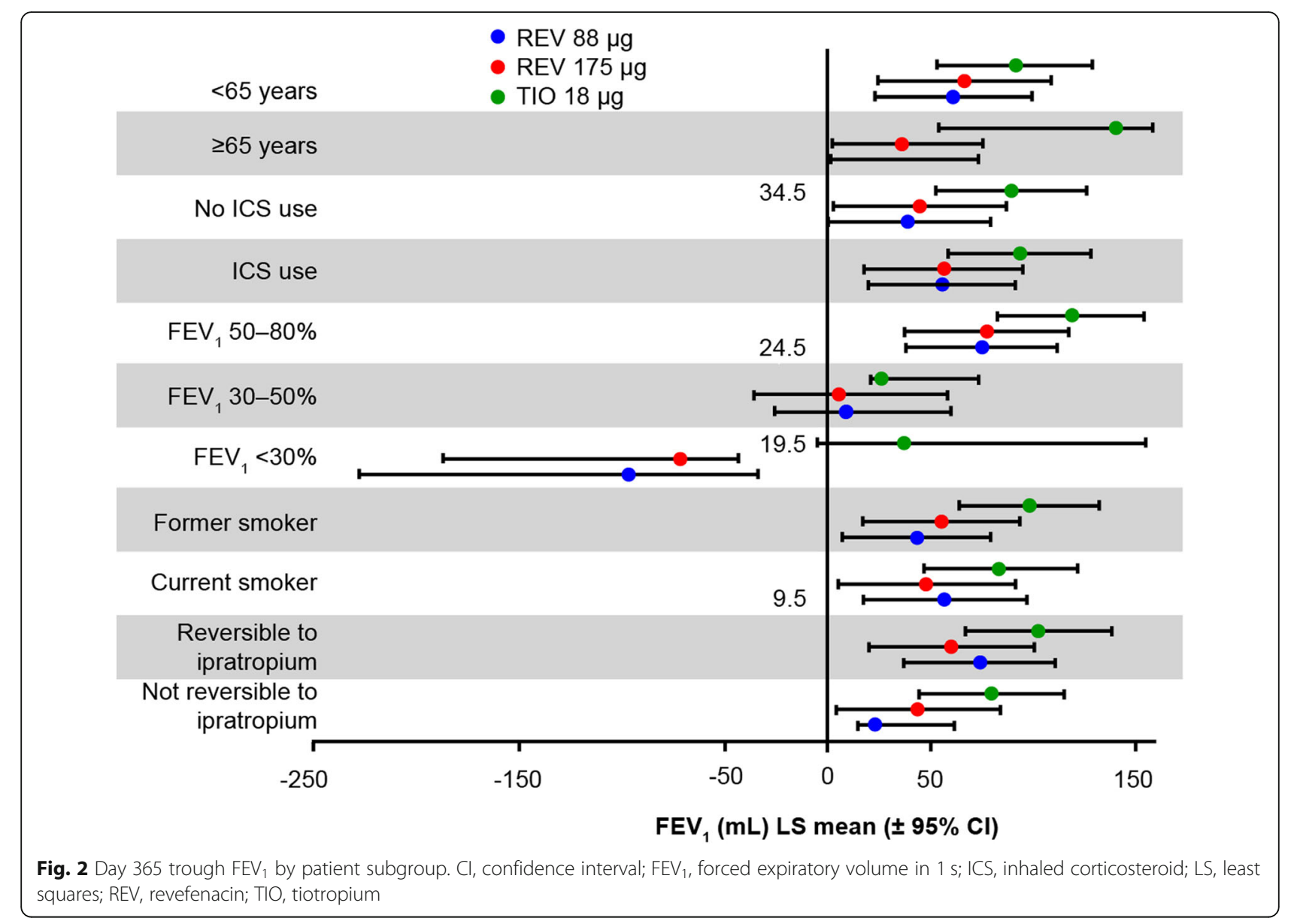

tiotropium group appeared to improve during the final 3 months of treatment. The increase in $\mathrm{FEV}_{1}$ observed on Day 365 in the tiotropium group may have been the result of the disproportionate number of poor performers (assessed by trough $\mathrm{FEV}_{1}$ ) who discontinued tiotropium during the final 3 months of treatment. The effect of revefenacin on trough $\mathrm{FEV}_{1}$ in this trial is consistent with that seen in previous studies $[7,13]$.

Analysis of withdrawal rates indicated that a higher proportion of subjects withdrew from both revefenacin arms than the tiotropium arm overall and during each 3 -month treatment period. The slightly higher overall rate of AE-related withdrawals, in particular withdrawals due to dyspnea ( $1.8 \%$ and $2.5 \%$ in the revefenacin $175 \mu \mathrm{g}$ and $88 \mu \mathrm{g}$ groups, respectively, versus $0.6 \%$ in the tiotropium group) may explain this. The open-label design for the tiotropium treatment arm may have also influenced withdrawal rates. There is no evidence from the $\mathrm{FEV}_{1}$ data that patients withdrew due to lack of treatment efficacy. As the study population is comprised of a considerable amount of COPD patients with severe markers of disease $\left(\mathrm{FEV}_{1}<50 \%, \mathrm{mMRC} \geq 2\right.$ or CAT $\left.\geq 10\right)$, it is possible these patients with more severe disease withdrew from the study at different rates. This would lead to a bias in the results, which is mainly driven by the open label nature of the study design. The dropout rate seen with revefenacin was similar to that seen in 12-month trials with other nebulized long-acting bronchodilators $[14,15]$.

With regard to patient subgroups, the concurrent LABA users in all treatment groups demonstrated significant improvements from baseline in trough $\mathrm{FEV}_{1}$. This result is comparable with the phase 3 revefenacin studies [7]. These findings are important to note as dual bronchodilation is increasingly recommended by COPD treatment guidelines [1]. Other subgroups (baseline smoking status, age category, current ICS use, responsiveness to ipratropium, and GOLD airflow) were also assessed to evaluate the consistency of treatment effects on trough $\mathrm{FEV}_{1}$ across a wider range of the ITT population. All three treatment groups achieved nominal improvements in trough $\mathrm{FEV}_{1}$ compared with baseline values. Overall, these subgroup results were similar with the phase 3 revefenacin studies [7].

Study limitations include lack of the open-label design for the tiotropium treatment arm, which likely led to different withdrawal rates for the revefenacin and tiotropium arms, and therefore skewed the efficacy results. In addition, the ability to draw conclusions on the efficacy 
A SGRQ score change from baseline (ITT)

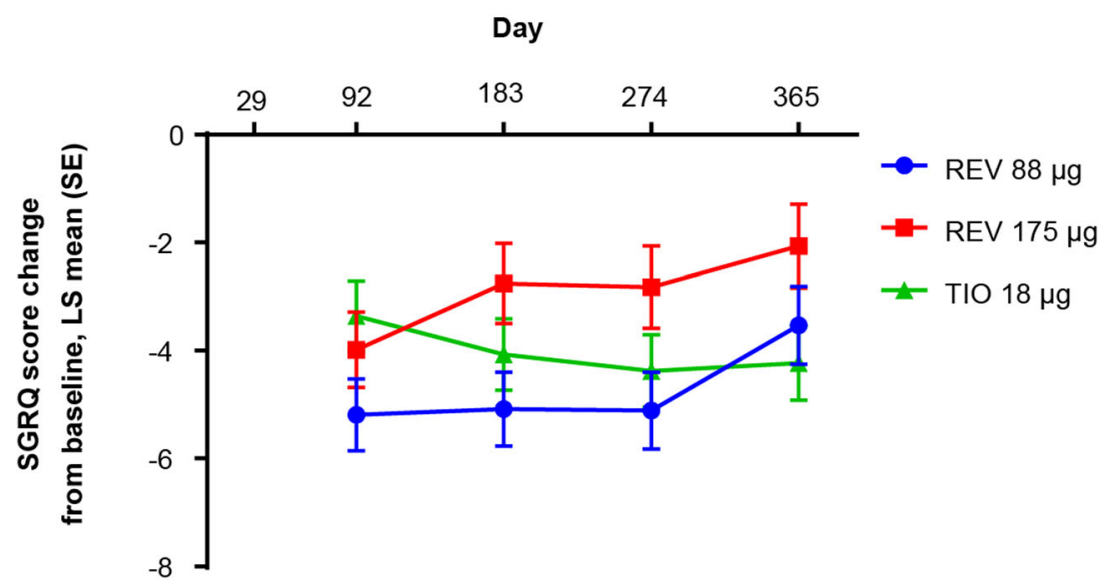

B

CAT score change from baseline (ITT)

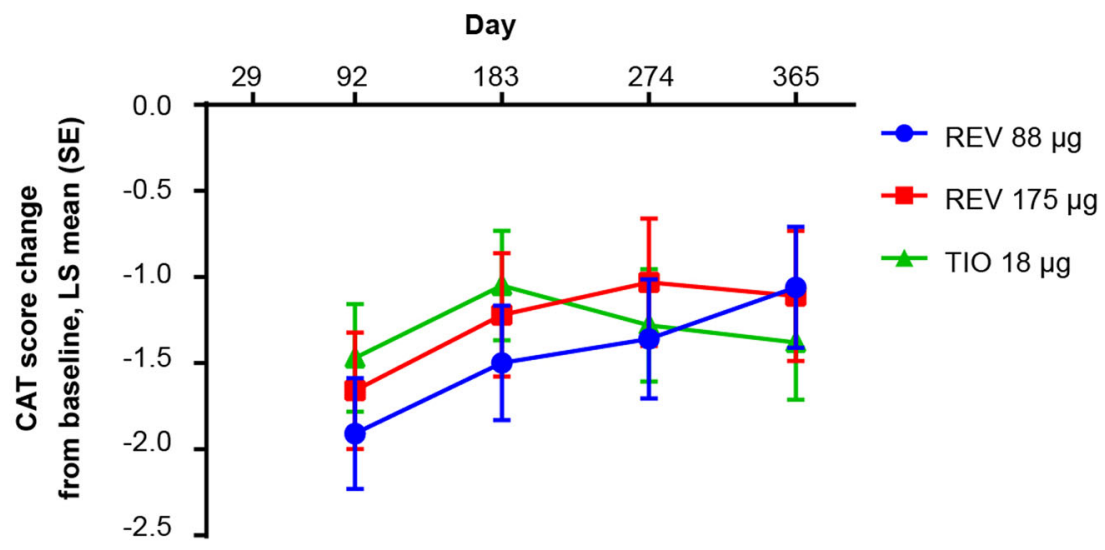

CCQ score change from baseline (ITT)

C

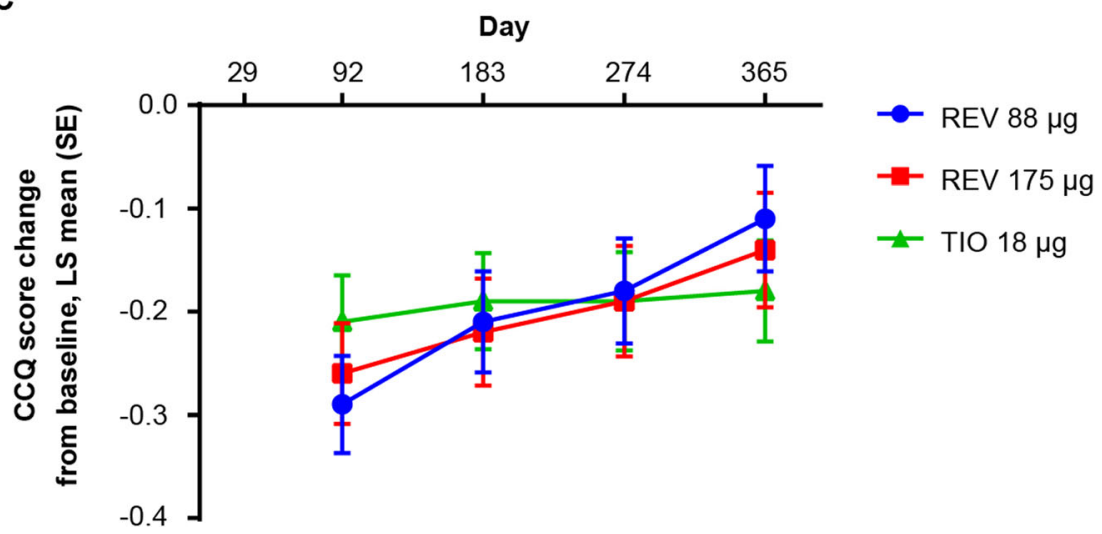

Fig. 3 (See legend on next page.) 
(See figure on previous page.)

Fig. 3 LS mean change in (a) SGRQ, (b) CAT and (c) CCQ from baseline for health outcomes assessments. For each health outcomes assessment, all treatment groups showed statistically significant $(p<0.05)$ changes from baseline at all time points. CAT, COPD Assessment Test; CCQ, Clinical COPD Questionnaire; COPD, chronic obstructive pulmonary disease; ITT, intent-to-treat; LS, least squares; REV, revefenacin; SE, standard error; SGRQ, St. George's Respiratory Questionnaire; TIO, tiotropium

of revefenacin versus tiotropium was limited because the study was not designed or powered to demonstrate statistically significant differences between treatment arms. Larger studies that are powered to assess efficacy are required to assess the comparative effects of these two treatments. However, the comparability of the results over 52 weeks is assuring.

\section{Conclusion}

In this study, which included a trial population with a broad range of disease severity, significant sustained improvements from baseline in trough $\mathrm{FEV}_{1}$ and respiratory health outcomes were demonstrated for the revefenacin $175 \mu \mathrm{g}$ dose and open-label tiotropium over 52 weeks. In line with the FDA approval for revefenacin $175 \mu \mathrm{g}$, these data further supports the use of revefenacin $175 \mu \mathrm{g}$ as a once-daily bronchodilator for the nebulized treatment of patients with COPD.

\section{Supplementary information}

Supplementary information accompanies this paper at https://doi.org/10. 1186/s12931-019-1187-7.

Additional file 1: Table S1. Patients who discontinued by study day: change from baseline in trough $\mathrm{FEV}_{1}(\mathrm{~mL})$ at last assessment before withdrawal.

\section{Abbreviations}

AE: Adverse event; BDI/TDI: Baseline and Transition Dyspnea Index; BMI: Body mass index; CAT: COPD Assessment Test; CCQ: Clinical COPD Questionnaire; Cl: Confidence interval; COPD: Chronic obstructive pulmonary disease; EXACT-PRO: EXAcerbation of Chronic Pulmonary Disease Tool-Patient Related Outcome; FEV 1 : Forced expiratory volume in $1 \mathrm{~s}$; FVC: Forced vital capacity; GOLD: Global Initiative for Chronic Obstructive Lung Disease; ICS: Inhaled corticosteroid; ITT: Intent-to-treat; LABA: Long-acting $\beta$-agonist; LAMA: Longacting muscarinic antagonist; LS: Least squares; MCID: Minimal clinically important difference; mMRC: modified Medical Research Council; REV: Revefenacin; RMMM: Repeated measures mixed-effect model; SD: Standard deviation; SE: Standard error; SGRQ: St. George's Respiratory Questionnaire; TIO: Tiotropium; y: years

\section{Acknowledgements}

The authors acknowledge Gautam Bijur, PhD, for medical writing and Paula Stuckart for editorial assistance in the preparation of the manuscript (Ashfield Healthcare Communications, Middletown, CT, USA).

\section{Authors' contributions}

JFD, EK, SS participated in data acquisition, and data analysis/interpretation. $\mathrm{BH}, \mathrm{SP}, \mathrm{LD}, \mathrm{CNB}, \mathrm{EJM}, \mathrm{GC}$ participated in study design, data acquisition, and data analysis/interpretation. All authors contributed to manuscript drafting and/or critical revision, approved the final manuscript and agree to be held accountable for all aspects of the work.

\section{Funding}

This study was funded by Theravance Biopharma, Ireland Limited Inc. (Dublin, Ireland). Mylan Inc. (Canonsburg, Pennsylvania, USA) and Theravance
Biopharma US, Inc. (South San Francisco, CA, USA) funded medical writing support.

\section{Availability of data and materials}

Theravance Biopharma (and its affiliates) will not be sharing individual de-identified participant data or other relevant study documents.

Ethics approval and consent to participate

The trial was conducted in accordance with the principles of the International Council on Harmonisation of Technical Requirements for Pharmaceuticals for Human Use guideline for good clinical practice [9], and the code of ethics of the World Medical Association's Declaration of Helsinki [10], and all patients provided written informed consent.

\section{Consent for publication}

Not applicable

\section{Competing interests}

B.H., S.P., L.D., E.J.M. and G.C. are current employees of Theravance Biopharma US, InC.

C.N.B was an employee of Theravance Biopharma US, Inc. at the time this study was conducted.

J.F.D. is a consultant and advisory committee member for Mylan Inc., Theravance Biopharma, Sunovion Pharmaceuticals, AstraZeneca, and GSK. S.S. is a consultant and advisory committee member for Theravance Biopharma US, Inc., and received research support from Mylan Inc. E.K. has participated in consulting, advisory boards and speaker panels, or received travel reimbursement for Amphastar, AstraZeneca, Boehringer Ingelheim, GlaxoSmithKline, Mylan, Novartis, Oriel, Pearl, Sunovion, Teva and Theravance Biopharma. He has conducted multi-center clinical research trials for approximately 40 pharmaceutical companies.

\section{Author details}

${ }^{1}$ Pulmonary Medicine, UNC School of Medicine, Chapel Hill, NC, USA. ${ }^{2}$ Clinical Research Institute of Southern Oregon, PC, Medford, OR, USA. ${ }^{3}$ University at Buffalo, State University of New York, Buffalo, NY, USA. ${ }^{4}$ Theravance Biopharma US, Inc., 901 Gateway Boulevard, South San Francisco, CA 94080, USA.

Received: 21 December 2018 Accepted: 11 September 2019

Published online: 30 October 2019

\section{References}

1. GOLD: Global Initiative for Chronic Obstructive Lung Disease. 2018.

2. HIGHLIGHTS OF PRESCRIBING INFORMATION LONHALA ${ }^{\text {TM MAGNAIRTM }}$ (glycopyrrolate) inhalation solution, for oral inhalation [https://www. accessdata.fda.gov/drugsatfda_docs/label/2017/208437lbl.pdf].

3. HIGHLIGHTS OF PRESCRIBING INFORMATION YUPELRI ${ }^{\oplus}$ (revefenacin) inhalation solution, for oral inhalation [https://www.accessdata.fda.gov/ drugsatfda_docs/label/2018/210598s000lbl.pdf].

4. Steinfeld T, Pulido-Rios MT, Chin K, King K, Huang JX, Lee TW, Jasper JR, Ji Y, Hegde S, Mammen M. In vitro characterization of TD-4208, a lung-selective and long-acting muscarinic antagonist bronchodilator [abstract]. Am J Respir Crit Care Med. 2009;179:A4553.

5. Baldwin M, McConn D, Potgieter P, Steinfeld T, Quinn D, Moran E. Singledose pharmacokinetics of TD-4208, a novel long-acting muscarinic antagonist, in patients with COPD [abstract]. Am J Respir Crit Care Med. 2013;187:A1496

6. Quinn D, Barnes CN, Yates W, Bourdet DL, Moran EJ, Potgieter P, Nicholls A, Haumann B, Singh D. Pharmacodynamics, pharmacokinetics and safety of revefenacin (TD-4208), a long-acting muscarinic antagonist, in patients with chronic obstructive pulmonary disease (COPD): results of two randomized, double-blind, phase 2 studies. Pulm Pharmacol Ther. 2018;48:71-9. 
7. Ferguson G, Feldman G, Pudi K, Barnes C, Moran E, Haumann B, Pendyala S, Crater $\mathrm{G}$. Improvements in lung function with nebulized Revefenacin in the treatment of patients with moderate to very severe COPD: results from two replicate phase III clinical trials. Chronic Obstr Pulm Dis. 2019;6:154-65.

8. Donohue J, Kerwin E, Sethi S, Haumann B, Pendyala S, Dean L, Barnes C,

Moran E, Crater G. Revefenacin, a once-daily, lung-selective, long-acting muscarinic antagonist for nebulized therapy: safety and tolerability results of a 52-week phase 3 trial in moderate to very severe chronic obstructive pulmonary disease. Respir Med. 2019;153:38-43.

9. Integrated addendum to $\mathrm{ICH}$ harmonised guideline: guideline for good clinical practice E6 (R2) [https://goo.gl/CFOmR3].

10. Helsinki. World medical association declaration of Helsinki: ethical principles for medical research involving human subjects. JAMA. 2013;310:2191-4.

11. Spirometry for health care providers [https://goldcopd.org/wp-content/ uploads/2016/04/GOLD_Spirometry_2010.pdf]

12. Leidy N, Murray L, Jones $P$, Sethi S. Performance of the EXAcerbations of chronic pulmonary disease tool patient-reported outcome measure in three clinical trials of chronic obstructive pulmonary disease. Ann Am Thorac Soc. 2014;(3):316-25.

13. Pudi KK, Barnes CN, Moran EJ, Haumann B, Kerwin E. A 28-day, randomized, double-blind, placebo-controlled, parallel group study of nebulized revefenacin in patients with chronic obstructive pulmonary disease. Respir Res. 2017;18:182

14. Donohue J, Hanania N, Fogarty C, Campbell S, Rinehart M, Denis-Mize K. Long-term safety of nebulized formoterol: results of a twelve-month openlabel clinical trial. Ther Adv Respir Dis. 2008;(4):199-208.

15. Donohue J, Hanania N, Sciarappa K, Goodwin E, Grogan D, Baumgartner R, Hanrahan J. Arformoterol and salmeterol in the treatment of chronic obstructive pulmonary disease: a one year evaluation of safety and tolerance. Ther Adv Respir Dis. 2008;2:37-48.

\section{Publisher's Note}

Springer Nature remains neutral with regard to jurisdictional claims in published maps and institutional affiliations.

Ready to submit your research? Choose BMC and benefit from:

- fast, convenient online submission

- thorough peer review by experienced researchers in your field

- rapid publication on acceptance

- support for research data, including large and complex data types

- gold Open Access which fosters wider collaboration and increased citations

- maximum visibility for your research: over $100 \mathrm{M}$ website views per year

At $\mathrm{BMC}$, research is always in progress.

Learn more biomedcentral.com/submissions 